\title{
Bankruptcu Risk Assessment Measures of Polish SMEs
}

\author{
HALINA CHŁODNICKA ${ }^{\mathrm{a}}$, GRZEGORZ ZIMON ${ }^{\mathrm{b}}$ \\ Department of Finance, Banking and Accounting \\ Rzeszow University of Technology \\ Al. Powstancow Warszawy 12, Rzeszow 35-959 \\ POLAND \\ ahach@,prz.edu.pl, ${ }^{b}$ gzimon@prz.edu.pl
}

\begin{abstract}
The accuracy of economic decisions depends on the quality of financial information, mainly derived from financial statements prepared by business entities and other units. Thus, there is a need to create so-called information systems for early warning. Good information could protect many entities from the risk of bankruptcy. This is particularly true for micro, small and medium-sized business entities. For such entities there is a need to create simple indicators informing about the impending financial crisis, most often associated with the loss of the ability to settle current liabilities. The aim of the article is to present a group of financial indicators on the basis of which managers can easily and most importantly very quickly assess the possibility of financial difficulties arising, which will result in the bankruptcy of an individual. Most importantly, the indicators presented can be used by managers of small enterprises with great ease. The indicators presented are primarily addressed to a group of small and medium-sized enterprises thanks to which managers can protect an enterprise against bankruptcy.
\end{abstract}

Key-Words: - bankruptcy, risk, small and medium enterprises

JEL Classification: G01, G33,

Received: September 26, 2019. Revised: January 11, 2020. Accepted: January 21, 2020.

Published: January 23, 2020.

\section{Introduction}

Over the years, the information content and the construction of financial reports have changed significantly. However, the data presented in the financial statements are not very legible for ordinary users and for many analysts "foggy" [1]. There are authors who believe that adopting IFRS raises the quality of accounting [2] but there are also those who claim differently $[3,4]$. The financial statement should provide transparent information because correct information could protect many entities from the risk of bankruptcy. This is particularly true for micro, small and medium-sized business entities that do not benefit from simplifications [5] they are most often victims of payment blocks that lead to bankruptcy $[6,7,8,9,10]$.

In Poland, the structure of entities that in the years 2010-2017 declared bankruptcy including their legal form was presented as follows: a limited company (58.4\%), a natural person $(22.6 \%)$, a jointstock company (7.8\%), general partnership (4.2\%), limited partnership (2.6\%), cooperative (2.1\%), a civil partnership $(1.4 \%)$, others $(0.9 \%)$ [11]. For many years, limited companies constitute the largest share among bankrupt entities. The reasons are different. First of all, it is necessary to look at these smaller economic entities so that their information would be such that it would protect them from bankruptcy. In general, financial crises that lead to payment bottlenecks are the most important reason for the bankruptcy of small and medium-sized enterprises. They are most affected by small and medium-sized enterprises that do not have financial reserves. The second important factor that strongly influences the financial situation of enterprises are mistakes made by the management. The owners have the impact on this area, the managers can also do a lot in this matter, even by increasing their knowledge. In this article a group of financial indicators, which can be an excellent source of information on the financial security of small and medium-sized enterprises, is discussed. In the case of large entities and capital groups, the group of indicators presented should be enriched with more complicated financial models. Over the years, the information content and the construction of financial reports have changed significantly. Good information could protect many entities from the risk of bankruptcy.

In Poland, the structure of entities that in the years 2010-2017 declared bankruptcy including their legal form was presented as follows: a limited company $(58.4 \%)$, a natural person $(22.6 \%)$, a jointstock company (7.8\%), general partnership (4.2\%), limited partnership (2.6\%), cooperative $(2.1 \%)$, a civil partnership (1.4\%), others $(0.9 \%)$ [11]. For 
many years, limited companies constitute the largest share among bankrupt entities. The reasons are different. First of all, it is necessary to look at these smaller economic entities so that their information would be such that it would protect them from bankruptcy [12]. In general, financial crises that lead to payment bottlenecks are the most important reason for the bankruptcy of small and mediumsized enterprises. They are most affected by small and medium-sized enterprises that do not have financial reserves. The second important factor that strongly influences the financial situation of enterprises are mistakes made by the management. The owners have the impact on this area, the managers can also do a lot in this matter, even by increasing their knowledge. In this article a group of financial indicators, which can be an excellent source of information on the financial security of small and medium-sized enterprises, is discussed. In the case of large entities and capital groups, the group of indicators presented should be enriched with more complicated financial models.

\section{Literature Review - Aspects of Bankruptcy of Small and Medium- Sized Business Entities}

The goal of every business entity should be early recognition of economic risk and undertaking measures to reduce its size.

The security can be treated as p roviding the enterprise with the maximum possible protection, preventing losses or guaranteeing compensation for losses. Taking into account the risk and its security, it is assumed that the entity has no i ntention or necessity to liquidate or deplete the existing size of operations. This rule, however, does not apply if the factual or legal status does not allow treating the entity as a co ntinuing activity. This means that the risk taken has become a threat, and this has led to the necessity of putting it in a state of terminating its operations and taking certain legal actions. Legal actions taken to close a business depend on the legal form of the business. The termination of business activity by a $n$ atural person may be the result of deleting from the business activity register as well as the declaration of bankruptcy and liquidation of economic activity during the bankruptcy proceedings.

The bankruptcy of an economic entity is a legal institution that aims to protect the rights of creditors by seizing and optimal satisfaction from the debtor's assets. Bankruptcy is a kind of execution as it leads to state intervention through government bodies.
The bankruptcy of the entrepreneur takes place in three areas: economic, legal and psychological [13]:

- on the economic level, there is a p ermanent loss of payment capacity, property shortage, or both of these phenomena

- the formal and legal aspect is the decision of the court announcing the bankruptcy of an entrepreneur who fails to meet its obligations in cash or in kind,

- psychological aspect is the consciousness of the debtor or the creditor of the occurrence of economic and legal premises for the declaration of bankruptcy,

- he bankruptcy estate management plan is prepared by the trustee, it is a kind of strategic plan that determines the most appropriate business strategy based on the analysis of the current state of the company. The strategy of operation consists of the basic goals, methods of action and measures necessary to achieve the objectives.

As of the date of bankruptcy, the estate of the bankrupt becomes a m ass of bankruptcy, which serves to satisfy the bankrupt's creditors. The bankruptcy processes in Poland are long-lasting, the costs of these processes related to keeping the trustee's office, securing bankrupt property, costs of valuation and exploitation of this property, bailiff's orders for conducting the auction are high. The activity of the trustee is subordinated to the goal of optimization, satisfying the rights of creditors in a given function of time, with certain economic and legal values. An unacceptable practice is the depreciation and functional disintegration of the bankruptcy estate for reasons attributable to the receiver, who inadvertently managed the goods entrusted to him. It follows the principle of prohibiting risking over any measure. On the other hand, the trustee should remember to maintain the liquidity of the bankruptcy proceedings for the entire duration of the proceedings.

The declaration of bankruptcy towards the accounting unit does not absolve the bankrupt from the obligation to continue its operation during the enforcement proceedings. However, the fact of the declaration of bankruptcy changes these principles to a large extent, especially as regards the valuation of assets and liabilities as well as entity reporting.

The objective of the general purpose financial report is to provide the public with detailed economic decisions, information about the financial position, results and cash flow of the entity. The modern order of the market economy and the constant need to make difficult economic decisions 
connected with it causes a continuous increase in the requirements imposed on the content and quality of financial statements. according to the Law of Entrepreneurs, it duplicates the criteria developed in the European Commission Regulation.

Many simplification changes have been introduced, especially for micro and small entities, but here too the application criteria have been introduced. As it follows from art. 7 par. $2 \mathrm{~b}$ of the current year, a micro, small and an entity may resign from the prudence principle when valuating individual assets and liabilities in the area of impairment write-downs of assets and provisions for known risk, losses and the effects of other events. In turn on the basis of art. 32 para. 7 and 33 para. 1 and art. 39 par. 6 the Accounting Act these units may also:

- make depreciation or redemption write-offs on tangible and intangible fixed assets according to the rules set out in tax regulations,

- do not create passive accruals of expenses related to future employee benefits, including retirement benefits [14].

The above simplifications, however, do not apply to limited liability companies, limited jointstock partnerships and general or limited partnerships whose all partners with unlimited liability are capital companies, limited joint-stock partnerships or companies from other countries with a legal form similar to those of the companies. The changes introduced make it easier for smaller business entities to keep accounts. However, it should be analyzed whether the information provided will answer the threat of bankruptcy. What indicators should be used so that this medium, small or micro entrepreneur can easily identify the entity's ability to continue operations and whether it is threatened and to what extent.

The financial statement is intended to answer the following questions [15]:

- Is the business profitable?,

- Will the entitu be able to continue it?

- How did the entity generate and use inventory, cash resources?

- Is it sufficient to quickly assess the situation of the individual?

- What about the assessment of the risk of bankruptcy?.

Simplifications in reporting should not hinder such an assessment, or it should be possible to create such indicators that will easily assess the threat condition of these smaller business units. The assessment should be simple, so that each small entrepreneur himself can assess the threat to the business. Indicators should be selected so that they clearly define their ability to continue as a going concern.

\section{An Assessment of Business Entities and the Risk of Continuing Operations}

The assessment of an economic entity to continue operations in many situations is very difficult, time-consuming, labor-intensive and requires knowledge and skills and can be expensive. For the "smaller" entities, a group of indicators should be used that would assess the ability to continue as a going concern. Over the years, perfect indicators have been developed to assess the financial condition of existing business entities. From these many indicators, one should choose those that will efficiently assess the situation of the operating entity. For entities that apply simplifications, only relevant indicators should be selected that will allow an efficient assessment of the financial situation at a given moment. The issue is very wide, because many indicators already exist, they can be used, but according to the authors, the layouts of reports change, so one can look for new, reliable indicators. The article uses an innovative indicator for the assessment, i.e. an indicator regarding the costs of bankruptcy. The costs of bankruptcy can be defined as a probable decrease in economic benefits in the reporting period, with a reliably determined value, causing a deterioration in the financial condition of an enterprise, entailing additional burdens determining the future bankruptcy process in the form of a decrease in assets or an increase in liabilities or provisions. The costs of bankruptcy are decreasing economic benefits in the reporting period or expenditure in the future by the entity that would bring those benefits to a reliably determined value, causing deterioration of the financial standing of the economic entity, entailing additional burdens determining the future bankruptcy process [15].

However, this indicator will be useful only when financial problems occur in the subject. This is an important issue in determining the risk of going concern. Maybe one should start the assessment from this indicator to eliminate the threat, and then specify other indicators constantly seeking innovative solutions. 
According to the authors of the article, only a skillful assessment of financial statements should serve in forecasting the economic difficulties of enterprises. It would be an easy assessment for entrepreneurs, first of all, as a warning soon enough. In the tests, an assessment was made on the basis of selected indicators, according to the authors sufficiently defining the financial situation. The studies also include the so-called bankruptcy costs to confirm the assumption that such costs are significant before the bankruptcy itself.

In the study the costs of bankruptcy included:

- Interest,

- impairment of assets,

- created reserves and accruals

In Court and Commercial Gazette, information related to bankruptcy proceedings is published, and from February 2016 also with restructuring proceedings. Their analysis allows creating a list of company bankruptcies and consumer bankruptcy. In 2019, until June 30, 171,449 announcements related to ongoing bankruptcy proceedings were published in the Gazette, including $3821 \mathrm{f}$ or consumer bankruptcy, 305 for company bankruptcy, and 224 for announcements about the initiation of restructuring proceedings.

At the end of June 2019 Court and Commercial Gazette published 305 bankruptcies of companies results from analyzes carried out by the Central Economic Information Center. It means that there are 9 bankruptcies fewer than in the analogous period of 2018, when there were 314 of them and 33 more than in the same period of 2017. If the number of bankruptcies remains at a si milar level in the second half of the year, in 2019 it should be 610 , against 615 in 2018.

As can be seen, most bankruptcy comes at the years 2011-2013. In subsequent years, bankruptcies are decreasing, this may be due to greater knowledge, awareness of running businesses and better management conditions.

It should also be noted that in the first half of 2019 applications for bankruptcy were dismissed in relation to 378 entities, and in 2018 all applications for bankruptcy were dismissed in relation to 562 entities, compared to 430 in 2017 and 151 in 2016. To establish the true trend, it should be taken into account that since January 2016, e ntities that had serious liquidity problems and settled liabilities instead of going bankrupt may start restructuring proceedings. Such procedures in $2018 \mathrm{w}$ ere 465 , compared to 348 in 2017 and 212 in 2016, and in the first half of 2019 there were 224 of them.

Most proceedings concern limited companies and individual business activities. This situation has been developing for many years. One can ask themselves if this is due to the limited responsibility for the proceedings. On the other hand, the collapse of entities of individual business activity constitutes about $30 \%$, in many cases it may refer to ignorance of management. The results, however, are not optimistic, as in recent years many entities have been created with such a management status. The problem of bankruptcy is still bothering scientists and entrepreneurs. New developments of models warning against bankruptcy are emerging. However, these models are useful for large, wealthy entrepreneurs who can afford to hire specialists to assess the risk of continuing operations. So what about those micro, small and medium-sized entrepreneurs who can rarely pay the costs of such a study. Very often, they assess their ability to continue their business "by eye" when analyzing the financial statements.

Financial statements play a v ery important role for investors as well as for potential investors and shareholders. Maybe you should think about the information for those interested and present information on the ability to continue the business by supporting them with appropriate indicators.

\section{Results - Indicators Informing about Business Bankruptcy}

The assessment of the risk of bankruptcy and bankruptcy of enterprises should be carried out in three stages:

- Stage one, using basic financial measures,

- Stage two, using indicators related to working capital management,

- Stage three, using detailed financial indicators, which can be described as the main symptoms informing about the bankruptcy of enterprises

The first group of indicators consists of basic indicators derived from financial analysis. The most important of them are presented in the table below. 
Table 1. Basic financial indicators informing about the risk of bankruptcy

\begin{tabular}{|l|l|}
\hline No. & Indicators \\
\hline 1 & Current liquidity ratio \\
\hline 2 & Quick ratio \\
\hline 3 & Debt equity ratio \\
\hline 4 & ROE \\
\hline 5 & ROS \\
\hline 6 & ROA \\
\hline 7 & Costs of bankruptcy/total costs \\
\hline 8 & Total liabilities/assets \\
\hline 9 & Total debt \\
\hline 10 & foreign capital/total assets \\
\hline
\end{tabular}

Source: author's own study

Of course, these indicators are well known. The higher the profitability results, the better the situation and the higher the level of profits. That means control of costs, including the costs of bankruptcy which may not be [16]. The financial liquidity ratio should be in the range of 1.2-2. $[17,18]$. On the other hand, the general debt ratio the higher the value of this indicator, the higher the risk is borne by the lender. It is often assumed that its value above 0.67 indicates an excessive credit risk [19]. The low level of the indicator indicates the financial independence of the company. At the same time, it does not allow taking full advantage of the leverage. The capital debt ratio shows the degree of engagement of liabilities in financing the enterprise's activity in relation to the level of equity involvement. It is assumed that the value of the indicator should be in the range from 1.0 to 3.0. It secures the repayment of the entity's obligations. The values of the ratio above 1 prove that the capital is heavily burdened with external capital. The net sales profitability ratio indicates that revenues from net sales are charged to all operating expenses, including costs resulting from tax burdens. The operating cost level indicator informs about the share of operating costs in sales revenue, and thus indicates what part of the sales revenues is intended to cover operating costs. High levels of the operating expense ratio (above 0.9) suggest an improper cost management policy in the enterprise. The values of the index exceeding $1.00 \mathrm{i}$ nform about the incorrect situation in which the operating costs exceed net sales (basic operational activity is deficit).
The second stage concerns indicators related to working capital management. The detailed indicators are presented in Table 2.

Table 2. Indicators related to working capital management

\begin{tabular}{|l|l|}
\hline No. & Indicators \\
\hline 1 & $\begin{array}{l}\text { Working capital = Current assets - short-term } \\
\text { liabilities }\end{array}$ \\
\hline 2 & Short-term receivables / short-term liabilities \\
\hline 3 & $\begin{array}{l}\text { Current assets - storage deposits / short-term } \\
\text { liabilities } \\
\text { (Storage deposits = stocks that are not easy } \\
\text { to sell. These stocks can be returns from } \\
\text { trusted contractors that cannot be returned to } \\
\text { the producer anymore. The company accepts } \\
\text { returns from its trusted contractors. It builds } \\
\text { its brand and increases the level of trust at } \\
\text { the expense of storage of goods, materials } \\
\text { with which it will have problems due to the } \\
\text { lack of interest of recipients.) }\end{array}$ \\
\hline 4 & $\begin{array}{l}\text { Operating cycle = duty conversion cycle }+ \\
\text { inventory conversion cycle (excluding } \\
\text { inventories referred to as storage deposits) }\end{array}$ \\
\hline 5 & $\begin{array}{l}\text { Liabilities conversion cycle - receivables } \\
\text { conversion cycle } \\
\text { Comparison of the cycle of conversion of } \\
\text { liabilities to suppliers in days to the cycle of } \\
\text { conversion of receivables from recipients in } \\
\text { days } \\
\text { (The positive result should be assessed } \\
\text { positively as it means a situation in which a } \\
\text { faster inflow of receivables from the dates of } \\
\text { settlement of liabilities appears.) }\end{array}$ \\
\hline
\end{tabular}

Source: author's own study

The indicators presented in table 2 inform about:

- the size of the buffer that protects the company against loss of liquidity

- position whether the entity is a lender or a borrower

- financial liquidity adjusted for storage deposits

- efficiency of current asset management

The third stage is based primarily on the assessment of the costs of bankruptcy. The most important indicators are presented in Table 3. 
Table 3. Detailed indicators of the risk of bankruptcy

\begin{tabular}{|l|c|}
\hline No. & Indicators \\
\hline 1 & $\frac{\text { total liabilities }}{\text { total assets }}$ \\
\hline 2 & $\frac{\text { costs of bankruptcy }}{\text { total assets }}$ \\
\hline 3 & $\frac{\text { costs of bankruptcy }}{\text { total liabilities }}$ \\
\hline 4 & $\begin{array}{c}\text { costs of bankruptcy } \\
\text { short-term liabilities }\end{array}$ \\
\hline 5 & $\frac{\text { costs of bankruptcy }}{\text { total costs }}$ \\
\hline 6 & $\frac{\text { costs of bankruptcy }}{\text { liquid assets }}$ \\
\hline 7 & $\frac{\text { costs of bankruptcy }}{\text { total revenues }}$ \\
\hline
\end{tabular}

Source: author's own study

In enterprises threatened with the interruption of the going-concern principle, especially at the time before the decision on the announcement of bankruptcy, the value of liabilities generally exceeds the level of assets. The costs of bankruptcy are primarily the costs of the loss of value of the assets sold, the costs of interest on liabilities overdue, the costs of compensation, severance payments, penalties, insurance, created reserves.

Among the indicators presented, it seems decisive to compare the total liabilities to total assets, which clearly define the state of the situation as well as the costs of bankruptcy to total revenues this ratio can still be divided into groups of revenues and costs of bankruptcy to liquid assets. The three indicators are enough to efficiently determine, even for internal purposes, the status of the business entity.

\section{Conclusion}

The accuracy of economic decisions depends on the quality of financial information, mainly derived from financial statements prepared by business entities and other units. It happens that among the participants of economic turnover the information presented remains unintelligible. The wide range of recipients of financial information in the contemporary world implies the need for constant searching for ever-more perfect decision-making tools.

In this respect, it is expected that universal, transparent, readable, short financial reports will be a reliable source of information. Therefore, in order primarily to protect the diverse interests of recipients of this information, it is extremely important to adhere to the quality features that should be met by created information. The proposal of the authors of the article refers to small entities that cannot apply simplifications in financial statements. Thus, the need to create so-called information systems for early warning. Their task is to inform the management of the unit about possible threats that the enterprise may face or - as in the case of early recognition systems - opportunities appearing in front of the enterprise. The financial indicators presented in the article divided into three groups, creating individual stages, are a p erfect early warning system for small and medium-sized enterprises providing information on impending threats that may lead to a company collapse.

\section{References:}

[1] G. Gotti, Discussion of Segment Disclosure Quantity and Quality under IFRS 8: Determinants and the Effect of Financial Analysts Earnings Forecast Errors, The International Journal of Accounting 51 (2016), 2016, pp. 462-463.

[2] H. Chen, Q. Tang, Y. Jiang, and Z. Lin, The role of international financial reporting standards in accounting quality: evidence from the European Union. Journal of International Financial Management and Accounting,. 21, 2010, pp. 220-228.

[3] S. Ahmed, M. Neel, and D. Wang, Adoption of ifrs improve accounting quality? Preliminary evidence. Contemporary Accounting Research.,2013, pp. 1344-1372.

[4] B. Van Tendeloo, A. Vanstraelen, Earnings management under German GAAP versus IFRS. European Accounting Reiew. 14, 2005, pp. $155-180$.

[5] H. Chłodnicka and G. Zimon. Financial Situation Assessment Dilemmas of Selected Capital Groups, Central European Conference in Finance and Economics, Herl'any, Slovak Republic, 2017, pp. 309-318.

[6] S. Ding, A. Guariglia, and J. Knight, Investment and financing constraints in China:does working capital management make a difference? J. Bank. Finance, 2013, vol. 37 (5), pp. 1490-1507.

[7] J. Enqvist, M Graham, and J. Nikkinen, The impact of working capital management on firm profitability in different business cycles: 
evidence from Finland. Res. Int. Bus.Finance, 2014, vol. 32, pp. 36-49.

[8] T.K. Vahid, G. Elham, A. Khosroshahi, and M.E Mohammadreza, Working capital management and corporate performance: evidence from iranian companies. Proced. Soc. Behav. Sci., 2012, vol. 62,2012, pp. 1313 1318.

[9] Z. Bei, and W. Wijewardana, Working capital policy practice: evidence from srilankan companies. Proced. Soc. Behav. Sci., 2012, vol. 40, pp. 695-700.

[10] G. Zimon, , An assessment of the Strategy of working capital management in Polish Energy Companies, International Journal of Energy Economics and Policy, 2019, 9(6), pp. 552556.

[11] R. Dankiewicz, Wpływ przeterminowanych należności na kondycję finansową przedsiębiorstw-analiza branżowa, Annales Oeconomia, Vol. 52, No 1,2018, pp.40-48.

[12]G. Zimon, $\mathrm{G}$ and H. Chlodnicka, Innovation in financial reporting: the aspect of the capital group, Marketing and Management of Innovations, 2, 2019, pp. 33-41. http://doi.org/10.21272/mmi.2019.203.

[13] H. Czajka, Przedsiębiorstwo w kryzysie, upadtości lub układ", Wydawnictwo Zrzeszenia Prawników, Warszawa, 1999, p. 17.

[14] H. Chłodnicka, Identyfikacja i systematyka kosztów upadłości, [in:] Nowak E.(ed), Modele rachunku kosztów i rachunkowości zarządczej, Prace naukowe no. 1039, W ydawnictwo Akademii Ekonomicznej we Wrocławiu, Wrocław, 2004, pp. 133-142.

[15] H. Chłodnicka, Sprawozdanie finansowe a pomiar efektów działalności przedsiębiorstwa w zagrożeniu kontynuacji działania, Uniwersytet Ekonomiczny we Wrocławiu, Wrocław, 2014, pp.87-101..

[16] D. Zimon and G. Zimon, The Impact of Implementation of Standardized Quality Management Systems on Management of Liabilities in Group Purchasing Organizations, Quality Innovation Prosperity, Volume 23 No.1 ,2019,60-73.

DOI: http://dx.doi.org/10.12776/qip.v23i1.1210

[17] S. Bougheas, S. Mateut, and P. Mizen, Corporate trade credit and inventories: New evidence of a trade-off from accounts payable and receivable, Spiros Bougheas Journal of Banking \& Finance 33, 2009, pp. 300-307
[18] G. Zimon, The Impact of Quality Management Systems on Financial Situation of SMEs Operating in Group Purchasing Organizations, WSEAS Transactions on B usiness and Economics, Volume 16, 2019, pp. 456-462.

[19] El Kalak, I., Azvedo, A., Hudson, R., Abd Karim, A., (2017). Stock liquidity and SMEs'likelihood of bankruptcy: Evidence fromthe US market, Research in International Business and Finance 42(2017), 2017, pp. 1383-1393. 